\title{
INFLUENCE OF MICROBIAL TRANSGLUTAMINASE ON SOME PHYSICAL AND MICROSTRUCTURAL PROPERTIES OF COW MILK COAGULUM SUPPLEMENTED WITH WHEY PROTEINS
}

Romeih E. A. H. and E. M. M. Hamad

Dept. Dairy science, Fac. Agric., Cairo University, Egypt.

\begin{abstract}
Recently, a focus on the utilization of whey proteins (WP) has been extensively investigated due to their nutritional value and their potential to enhance functional characteristics of the dairy product. The effect of microbial transglutaminase (TG) on the characteristics of skim-milk prepared with the addition of WP products ( $\alpha$ lactalbumin, $\beta$-lactoglobulin and whey protein isolate (WPI)) was studied. For comparison, full-fat and skim-milk gels without addition of TG were also examined. The results show that TG significantly $(P<0.05)$ increased the yield values and decreased curd firmness obtained by formagraph, compared to skim-milk gel without TG. Furthermore, addition of WP enhanced the reactivity of TG as indicated by the extended rennet coagulation time and the further less firmness of the curd. This result was confirmed by the appearance of new high molecular weight protein polymers bands in SDS-PAGE, particularly, within WPI and $\beta$-lactoglobulin treatments. The highest curd yield was obtained when WPI was added (an increase of $\sim 50 \%$, compared with the TG-treated skim-milk), while the $\alpha$-lactalbumin addition exhibited the least reactivity with TG on coagulation properties. Also, scanning electron microscope (SEM) analysis approved the same trend of the results represented in the more dense structure accompanied by finely dispersed clusters of WP strands attached to protein matrices with particular intense in WPI and $\beta$-lactoglobulin treatments. In conclusion, the cross-linking by TG with the addition of whey proteins intensely altered the functional properties of the resulting milk coagulum. This novel functionality of the milk coagulation network offers interesting possibilities for enhancing dairy products by adding whey proteins before treating milk with TG.

Keywords : Transglutaminase, cross-linking, Whey proteins, microstructure, formagraph.
\end{abstract}

\section{INTRODUCTION}

Transglutaminase (TG) is an enzyme (EC 2.3.2.13) that capable of forming both inter- and intra-molecular isopeptide bonds in and between many proteins by cross-linking of the $\gamma$-carboxyamide group of peptide bound glutamine residue (acyl donor) and primary amino group of lysine residue (acyle receptor), forming $\varepsilon(\gamma$-glutamyl)lysine linkages (Wróblewska et al., 2008; Jaros et al., 2010 ).

TG has been used by the food industries over the recent decades to improve the texture and to generally modify the functional properties of the prepared foods, i.e. seafood, surimi products, noodles and dairy products (Kuraishi et al., 2001). Various researches demonstrate the potential of TG performance with different food proteins such as caseins (Kruif et al., 2002; Mugurama et al., 2003), gluten (Bauer et al., 2003), oat globulin (Siu et al., 2002), myosin (Tseng et al., 2002) and soy proteins (Mugurama et al., 2003). 
Milk protein gels being made traditionally are considered stabilized mainly by weak non-covalent interactions. Introduction of new covalent bonds leads to gels which are, therefore, different in structure and functional properties. The use of TG offers such opportunity to improve the rheological and other quality properties of dairy products, which in-turne, has attracted considerable attention in dairy research (Nielsen et al., 1995; Schorsch et al., 2000).

Whey proteins (WP) compose about $20 \%$ of cow milk and are generally produced as a co-product of the cheese industry. In addition to the high potential nutritional value of the whey proteins and its easily digested feature, it possess cluster of functional properties including the hydration ability, emulsification, gelation, stabilization, whipping/foaming and thickening properties, that in turne excessively alter and modify the product quality attributes (Eissa and Khan, 2006).

Various studies have approved the capability of TG to work on whey proteins (Sharma et al., 2002; Rodriguez-Nogales, 2006; Gauche et al., 2008). The SDS-PAGE analysis indicated the reactivity of TG with the milkWP ( $\alpha$-lactalbumin and $\beta$-lactoglobulin) without the need for any prior treatment (Sharma et al., 2002 and Gauche et al., 2008). It is worthwhile to note that the researches generally deal with the isolated or concentrated milkWP mainly through its natural form or with other ingredients in aqueous solution forms. Instead, milk-WP polymerization by TG in the milk matrix (phase) has not been much reviewed. Accordingly, in the study presented herein, the influence of crosslinking between different whey protein products ( $\alpha$-lactalbumin, $\beta$-lactoglobulin and WPI) and casein via TG in milk was investigated. These effects were studied under chosen conditions that of which resembling production scheme of many cheese varieties with respect to soft cheese types. Therefore, glucono- $\delta$-lactone was added to slightly acidify the milk before rennet addition. Hence, acidic-rennet induced coagulation of fresh cow milk was performed. The functional impact of WPP addition and TG treatment on milk-gels were investigated by physical and microstructure means.

\section{MATERIALS AND METHODS}

Fresh cow milk was obtained from the Norwegian University of Life Science farm. A quantity of whole milk was kept as control, and the remaining amount of the milk was subjected to separation giving skim milk of $0.1 \%$ fat. The microbial rennet (CHY-MAX ${ }^{\mathrm{TM}}$ Plus, Christian Hansen, Hørsholm, Denmark) was used.

The whey protein products (WPPs) used were $\mathrm{BiPRO}^{\circledR}$, which is whey protein isolate (WPI), Davisco's Alpha-lactalbumin (Alpha) and Davisco's Beta-lactoglobulin (Beta) (Davisco Food International, INC., Minnesota, USA). The dispersion of WPPs in milk was made according to the manufacturer's recommendations. The WPPs were initially dispersed in a portion of the raw skim milk from their respective vats in a proportion of $0.2 \%$ $(\mathrm{w} / \mathrm{w})$ for all of them using a high speed blender for 2-5 min. 
The used microbial TG preparation was Activa ${ }^{\circledR}$ YG (E.C. 2.3.2.13) (Ajinomoto Foods Europe S.A.S., Hamburg, Germany), which had a declared specific activity of $100 \mathrm{U} \mathrm{g}^{-1}$ powder. TG was added at a concentration of $2 \mathrm{U} \mathrm{g}^{-1}$ milk proteins to the respective treatments.

Acid-rennet induced gelation was carried-out in six treatments. The experimental design was performed to compare full-fat milk and skim-milk gels as controls (without addition of TG and coded as $F$ and $S$ treatments, respectively) with four different skim-milk gels consisted of the following treatments: skim-milk with addition of TG, skim-milk with addition of $T G+$ Alpha, skim-milk with addition of $T G$ + Beta and skim-milk with addition of $T G$ + WPI; where are represented in codes STG, STG-Alpha, STG-Beta and STG-WPI, respectively. The factorial design were made with two factors: Replicate block (3 levels), and milk treatment (6 levels).

All milks were heat treated at $78^{\circ} \mathrm{C} / 2 \mathrm{~min}$ in double-walled stainlesssteel vats followed by cooling to $32^{\circ} \mathrm{C}$, glucono- $\delta$-lactone (GDL from Sigma, Italy) was added to all milk treatments as a powder $(0.5 \% \mathrm{w} / \mathrm{v}) 30$ minutes prior to rennet addition $(0.015 \%, \mathrm{v} / \mathrm{v})$. TG was added simultaneously with the GDL addition and prior to rennet addition for an incubation time of $30 \mathrm{~min}$.

The total nitrogen content (TN \%) was measured by the Kjeldahl method (International Dairy Federation (IDF), 1993). Total protein content was calculated by multiplying the $\mathrm{TN} \%$ by 6.38 . Milk fat content was determined by the Gerber method according to (Ling, 1963). Milk total solids (TS \%) content was determined according to (AOAC, 1990). pH was measured in the fresh milk samples and 30 min after the addition of GDL using a digital pH-meter PHM92 (MeterLab TM, Radiometer Analytical S.A., France). All samples were analyzed in triplicate.

The yield was determined by a centrifugation method according to Bönisch et al. (2008). The yield after centrifugation in \% (w/w) was defined as the weight of the gel attained after centrifugation in relation to the initial weight of milk sample All measurements were carried out in triplicate.

The gelation kinetics of the viscoelastic milk gels of all treatments were performed by formagraph (Lattodinamografo, FOSS ITALIA S.p.A., Via Belgio, 35127 Padova, Italy) according to the method of McMahon and Brown (1982).

Fig. 1 shows the output results of the Formagraph. Rennet clotting time (RCT) which is referred to coagulation time, required to achieve a curd firmness of $20 \mathrm{~mm}$ (K20) reflecting the firming rate of the curd and curd firmness (A30), which is measured 30 min after the addition of rennet were recorded at $32^{\circ} \mathrm{C}$. The overall time of every Formagraph run was $60 \mathrm{~min}$. Measurements were carried out in at least triplicate in the same milk sample.

For scanning electron microscopy (SEM) of the fresh prepared milk gels, small cylindrical pieces from the center of the gel blocks (approximately $3 \mathrm{~mm}$ in diameter and height) were prepared and examined according to Sandoval-Castilla et al. (2004) using a high vacuum Zeiss Scanning Electron Microscope EVO-50-EP (Carl Zeiss SMT Ltd., Cambridge CB1 3JS, UK) to view the samples at $5 \mathrm{KV}$ and magnification of 7500x. 


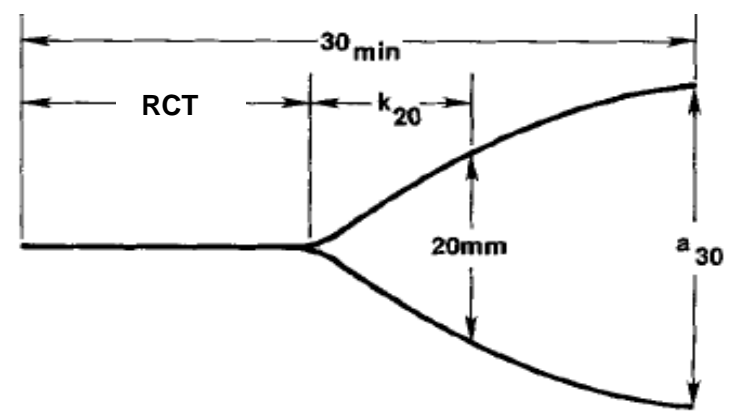

Fig. 1. A typical diagram of coagulation and curd firmness as a function of time obtained by the Formagraph (McMahon and Brown, 1982)

Sodium Dodecyl Sulfate Polyacrylamide Gel Electrophoresis (SDSPAGE) was carried by using a BIO-RAD Mini PROTEAN II unit. SDS-PAGE under reducing conditions has been used to estimate the relative molecular weight to evaluate the polymerization extent of the protein chains (Laemmli, 1970).

Data were statistically analyzed by ANOVA using general linear model of SPSS (ver. 11.0.1, SPSS Inc., USA, 2001), and significant differences $(P \leq 0.05)$ between treatments were determined.

\section{RESULTS AND DISCUSSION}

The average composition and some of the physicochemical properties of fresh cow milk used in the present study are given in Table 1. The total solids of skim milk were reduced as a result of skimming. On the other hand, pre-incubation of milk for 30 minutes after addition of GDL resulted in rather acidified milk ( $\mathrm{pH} \sim 5.9$ ) prior to renneting step.

Table (1): Composition and physicochemical properties of full-fat and skim-milks used in manufacture of milk-gels.

\begin{tabular}{lcc}
\hline & Full-fat milk & Skim-milk \\
\hline Fat \% & $3.35 \pm 0.17$ & $0.12 \pm 0.04$ \\
Protein \% & $3.31 \pm 0.05$ & $3.44 \pm 0.08$ \\
Total solids \% & $11.87 \pm 0.24$ & $9.07 \pm 0.15$ \\
pH & $6.68 \pm 0.02$ & $6.65 \pm 0.01$ \\
pH-30min & $5.94 \pm 0.06$ & $5.92 \pm 0.05$ \\
\hline
\end{tabular}

Values are means \pm standard deviation.

* pH values of milks after 30 min from GDL addition.

By the Formagraph technique, the progress of the curd formation can be detected. Table (2) shows milk-clotting parameters derived from formagraph at $32^{\circ} \mathrm{C}$. RCT values have increased significantly $(P<0.05)$ as a result of adding $T G$, and even rather higher within treatments of whey protein products addition ,compared to the control treatment ( $F$ and $S$ ). Increased 
coagulation times as a result of the pre-incubation of milk by TG reflecting the impact of the TG cross-linking on the primary enzymatic phase. This result was also described by O'Sullivan et al. (2002) and Bönisch et al. (2008). The $k$-casein molecule, which is located at the surface of the casein micelle, possesses four potential glutamine residues that are available as crosslinking sites rendering $k$-casein susceptible to TG, which in turn retard the lag phase of rennet-induced coagulation (Sharma et al., 2001; Tolkach \& Kulozik, 2005).

Table (2): Impact of TG treatment and addition of whey protein fractions on milk-clotting parameters derived from formagraph at $32^{\circ} \mathrm{C}$ and yield\%, as indicated by the analysis of variance.

\begin{tabular}{|l|c|c|c|c|}
\hline & RCT (min.) & K20 (min.) & A30 (mm) & Yield (\%) \\
\hline F & $8.08 \pm 0.14^{\mathrm{a}}$ & $5.92 \pm 0.29^{\mathrm{a}}$ & $27.01 \pm 1.03^{\mathrm{a}}$ & $32.23 \pm 0.75^{\mathrm{a}}$ \\
\hline S & $8.67 \pm 0.14^{\mathrm{a}}$ & $6.67 \pm 0.14^{\mathrm{a}}$ & $32.75 \pm 0.68^{\mathrm{b}}$ & $23.24 \pm 0.33^{\mathrm{b}}$ \\
\hline STG & $12.08 \pm 0.38^{\mathrm{b}}$ & $10.00 \pm 1.09^{\mathrm{b}}$ & $28.28 \pm 2.02^{\mathrm{a}}$ & $35.09 \pm 0.73^{\mathrm{c}}$ \\
\hline STG-Alpha & $14.25 \pm 0.50^{\mathrm{c}}$ & $11.92 \pm 0.52^{\mathrm{b}}$ & $23.35 \pm 0.50^{\mathrm{c}}$ & $43.48 \pm 1.00^{\mathrm{d}}$ \\
\hline STG-Beta & $15.33 \pm 0.52^{\mathrm{d}}$ & $14.58 \pm 1.01^{\mathrm{c}}$ & $19.53 \pm 1.20^{\mathrm{d}}$ & $48.83 \pm 0.19^{\mathrm{e}}$ \\
\hline STG-WPI & $14.58 \pm 0.38^{\mathrm{c}}$ & $14.33 \pm 0.58^{\mathrm{c}}$ & $21.56 \pm 0.69^{\mathrm{d}}$ & $52.31 \pm 0.58^{\mathrm{f}}$ \\
\hline
\end{tabular}
standard deviation.

Means with different superscripts in the same column are significantly differ $(P<0.05)$.

Furthermore, the significant increased $(P<0.05)$ RCT values within treatments of whey protein products (STG-Alpha, STG-Beta and STGWPI) ,compared to that of TG treated skim-milk without addition of whey proteins indicate that an induced and excessive cross-linked caseins performed through the pre-incubation time (30 min.) with TG ,that resulted in an extended clotting time. This trend of result confirms that whey proteins are favorable substances for its performance.

The Formagraph data presented in Table 2 obviously show that there was no significant difference between full-fat and skim milk treatments with respect to clotting time and curd firming rate values, whereas skim-milk gel exhibited a significant $(P<0.05)$ higher curd firmness, compared to the full-fat milk gel (A30-values increased by $21 \%$ ). This observation was expected due to the bereft of milk-fat in $S$ treatment. In this context, treating skim-milk with TG resulted in a significant reduction $(P<0.05)$ in A30-values and reaching no significance with full-fat treatment $(F)$. As previously concluded by Bönisch et al. (2008), the present obtained results indicate that not only the primary phase (lag phase) of rennet coagulation, but in particular the secondary phase and the formation of a three dimensional gel structure appears to be affected significantly by TG.

Regarding the impact of whey proteins addition, it is noticed that STG-Beta treatment obtained the highest K20-values and the lowest A30values. It can be clearly indicated from $\mathrm{A} 30$-values that all whey protein treatments were significantly $(P<0.05)$ softer than the TG-treated skim milk (Table 2). This reduction in curd firmness was of $17 \%, 31 \%$ and $24 \%$ for STG-Alpha, STG-Beta and STG-WPI treatments, respectively, compared to that of the TG-treated skim milk. Surprisingly, whey protein treatments were 
significantly $(P<0.05)$ softer than the full-fat treatment $(\mathrm{F})$, reflecting a great enhanced reactivity of the protein cross-linking, and hence altering the functional properties of milk-gels.

The curd yield (\%) after centrifugation are shown in Table 2. It appeared that the yield of full fat milk gels is more than the skim milk gels which, is of normal finding due to the presence of milk fat. A significant increase $(P<0.05)$ in curd yield $(\sim 51 \%)$ was observed in skim milk when treated with TG (Table 2). Bönisch et al. (2008) elucidated that the increased curd yield is rather explained by the enhanced serum binding of the gel network stabilized by additional covalent bonds than by the incorporation of native WP into the gel network.

Furthermore, addition of whey protein products significantly $(P<0.05)$ increased the curd yield compared to STG treatment. This increase was of 23\%, 39\% and $49 \%$ for STG-Alpha, STG-Beta and STG-WPI treatments, respectively (Table 2). Bönisch et al. (2008) elucidated that the increased curd yield is rather explained by the enhanced serum binding of the gel network stabilized by additional covalent bonds than by the incorporation of native WP into the gel network. Additionally, the highest yield value obtained by STG-WPI might be explained not only through its enhancement of TG reactivity, but also to its well-known higher water holding capacity as stated by Truong et al. (2004) and Li et al. (2005). The more hydrated texture and more excessive cross-linking action may together contribute to a softer and less firm texture obtained in STG-Beta and STG-WPI treatments compared to both control treatments ( $F$ and $S$ ) and STG treatment.

The electrophoresis profile in SDS-PAGE was carried out in order to confirm the polymerization reaction of whey protein fractions with milk proteins by TG (Fig. 2). The extent of cross-linking was demonstrated by disappearance of protein bands and/or appearance of new high molecular weight protein polymers bands. It could be noticed from lanes 2 and 3 that without addition of TG, no cross-linking was observed. The appearance of high molecular weight bands in lanes 4,5 and 6 shows different rates of cross-linking between whey protein fractions added and milk proteins. Moreover, it could be noticed that the addition of $\alpha$-lactalbumin and $\beta$ lactoglobulin fractions resulted in an increase in the band sizes of these fractions, while the addition of WPI resulted in the increase in the size of bands of both $\alpha$-lactalbumin and $\beta$-lactoglobulin (Fig. 2).

As indicated in the SDS-PAGE patterns (Fig. 2), the intensity of the protein polymer formed due to cross-linking catalyzed by TG was high when $\beta$-lactoglobulin and WPI were added, while it was low when $\alpha$-lactalbumin was added. This suggests that the rate of cross-linking was bigger in case of $\beta$-lactoglobulin and WPI treatments than that in the case of $\alpha$-lactalbumin treatment. In fact, the rate of crosslinking by TG is dependent on the macromolecular structure of each protein substrate and reactive glutamine residues available. 


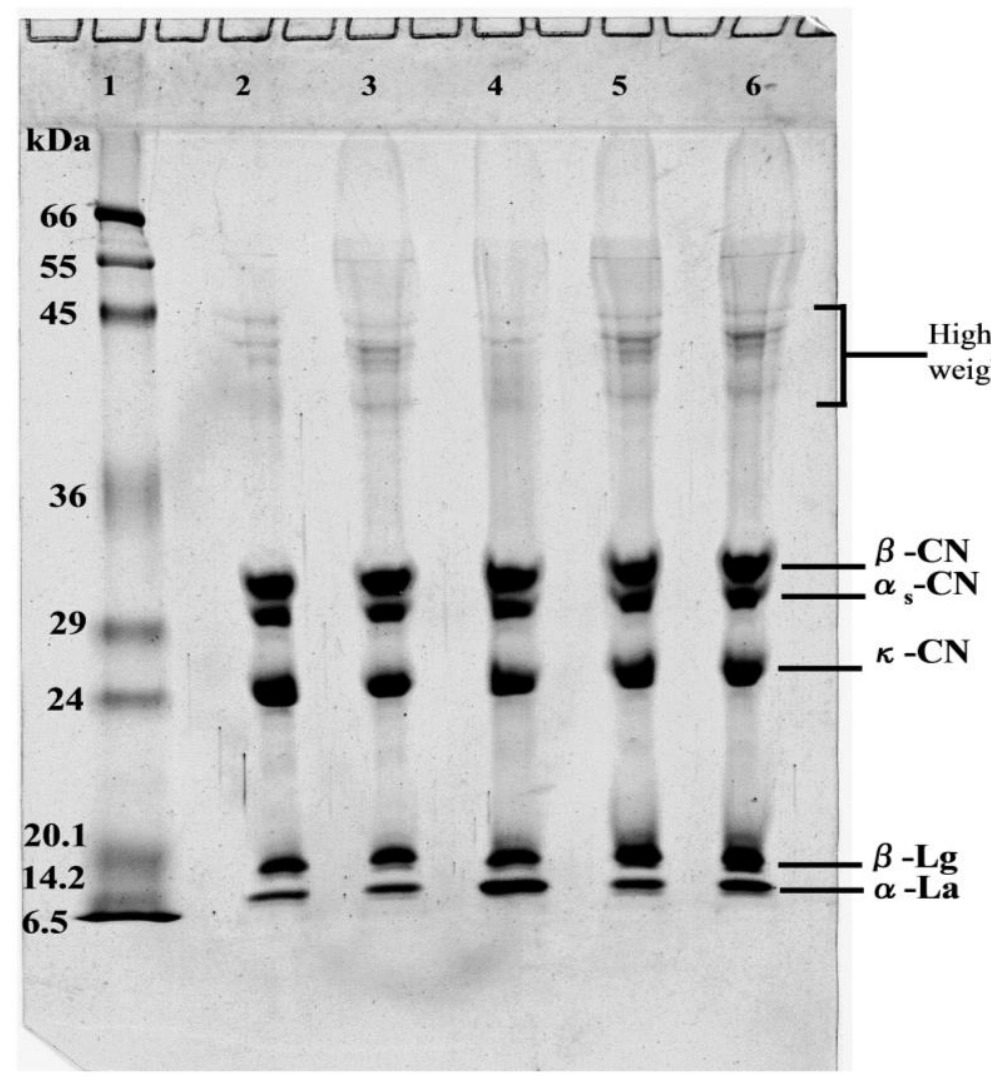

Fig (2): SDS-PAGE gel. Lane 1 is the Molecular weight marker. Lane 2 is untreated milk sample, lane 3 milk sample treated with transglutaminase. Lane 4,5 and 6 are milk mixed with $\alpha$ lactalbumin, $\beta$-lactoglobulin and whey protein isolate, respectively, and treated with TG.

Therefore, the low rate of cross-linking with a-lactalbumin might be due to its lower content of reactive residues (8 glutamine residues and 12 lysine residues) than $\beta$-lactoglobulin (16 glutamine residues and 15 lysine residues) in its protein chain (Gauche et al., 2008). These data support the obtained results of formagraph and yield (Table 2). In fact, the full fat milk sample was not used in this test as the previous results showed that the presence of fat in milk did not affect the extent of cross-linking of milk proteins by TG (Hinz et al., 2007).

The SEM micrographs of cow milk gels as influenced by addition of protein cross-linking and whey protein fractions are shown in Fig. 3. The protein matrix (gray area) formed a continuous phase permeated by an amorphous system of voids filled with serum, which in turn revealed the spatial dimensions of these images.

As it might be seen from these micrographs, there is an obvious and large variation in the microstructural properties of full-fat and skim-milk gels 
( $F$ and $\mathrm{S}$ ) as control treatments without addition of TG (Fig. 3A and 3B). A spongy-like structure was obtained in skim-milk gel, whereas a continuous phase of smooth protein aggregate network characterized by a more compacted and dense structure accompanied by less voids revealed in the full-fat milk gel, where the spherical fat globules (pointed with white arrows) were obviously dispersed and scattered uniformly throughout the protein matrices. This result is in parallel with that of Lobato-Calleros, et al. (2002 and 2007) and Liu et al. (2008).

The manifested microstructure in Fig. $3 \mathrm{C}$ clearly revealed that addition of TG to skim-milk (STG treatment) promoted regularly aggregated protein matrices accompanied by homogeneous systematic pores that obviously much finer and less in size compared to that of control treatments ( $\mathrm{F}$ and S; Fig. 3A and 3B, respectively). This expressed manner of protein matrix might attribute to the influence of $T G$ addition that is capable of forming both inter- and intra-molecular isopeptide protein bonds (Kuraishi et al., 2001). Moreover, remarkable clusters of cross-linked strands and partially fused protein aggregates (pointed with black arrows) were noticed in this micrograph which most probably resulted from the cross-linking action between whey protein particles and casein micelles as an impact of TG addition. These observations in accordance to those reported by Kruif et al. (2002) and Bönisch et al. (2008).

As it might be seen in Fig. 3D, 3E and 3F, the addition of whey protein products promoted the overlapping of cross-linking protein aggregates (appeared in the images as whiter gray areas and pointed with black arrows) that distributed irregularly through the gel matrix giving much finely dispersion and dense vision of the protein matrices ,compared to that of skim milk treated with TG and without addition of whey protein products (Fig. $3 \mathrm{C}$ ). These results are conformable with the gelation kinetics obtained by formagraph (Table. 2), and are in agreement with those of Lobato-Calleros, et al. (2007) and Supavititpatana, et al. (2009) in white fresh cheese and cornmilk yogurt, respectively.

Despite that, a uniform addition of whey protein products $(0.2 \% \mathrm{w} / \mathrm{w})$ to the skim milks was considered throughout preparation of those treatments (STG-Alpha, STG-Beta and STG-WPI), a noticeable changes in microstructure properties was evident among them.

Obviously, addition of $\alpha$-lactalbumin fraction tended to cause the least influence on the milk-gel network structure, whereas a more inclusion of finely cross-linked strands and protein aggregates (pointed with black arrows) resulted in within treatments of $\beta$-lactoglobulin and WPI addition as it could be seen in Fig. 3D, 3E and 3F, respectively. This finding goes in parallel with the results trend obtained by SDS-PAGE electropherograms, as the addition of $\beta$-lactoglobulin and WPI tended to cause inclusion of a high cross-linked protein aggregates. This in turn resulted in more homogenous dense structure, which rather resembled, to some extend that of full-fat structure regardless the presence of milk-fat globules. However, the addition of $\alpha$ lactalbumin showed minimal changes in the microstructure (Fig. 3D), which is most propably attributed to the weak reactivity with the TG, as earlier 
explained. This finding consistent with the observations of Puventhiran et al. (2002) and Supavititpatana et al. (2009).
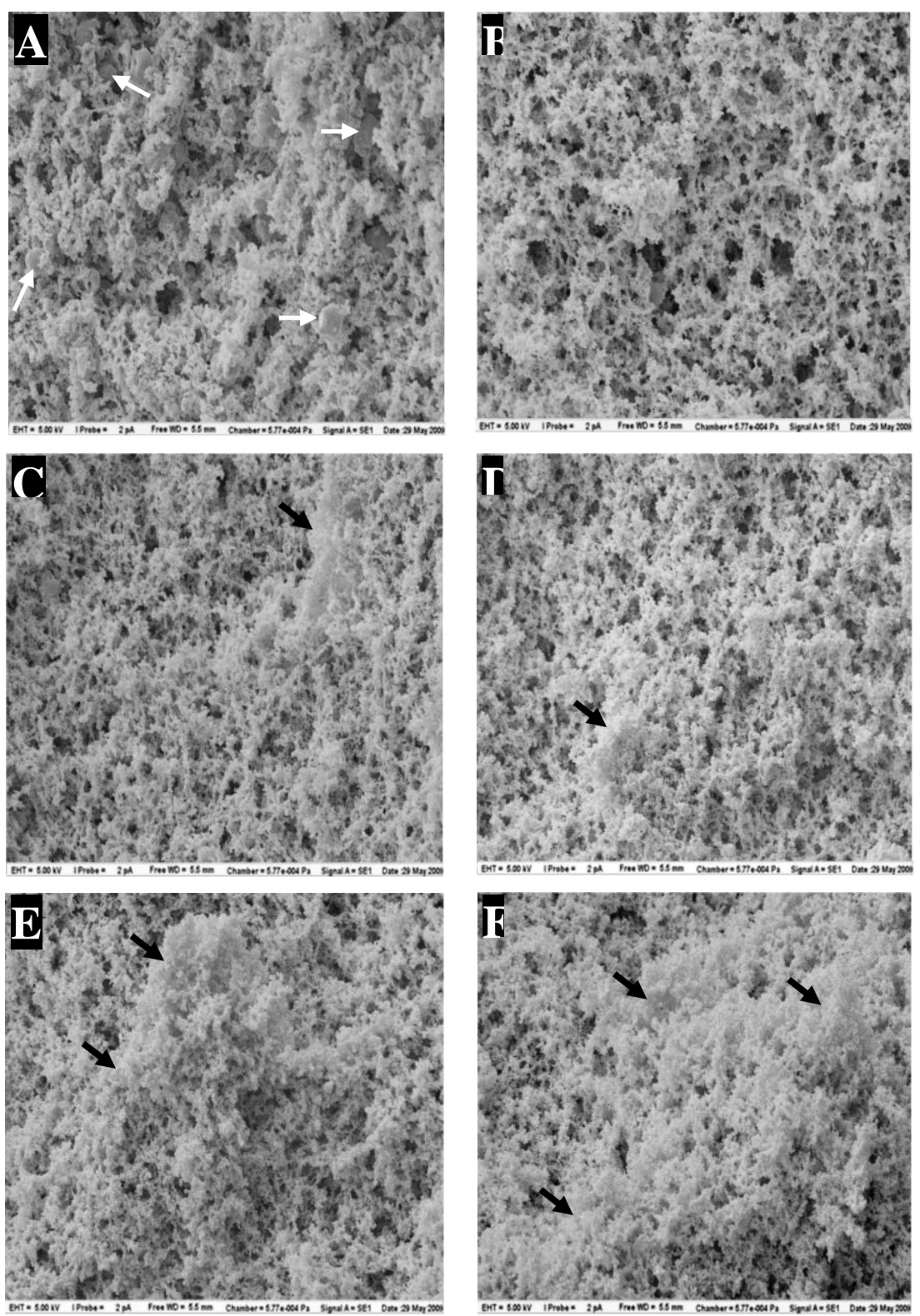

Fig (3): Scanning electron micrographs of rennet-induced gel of; (A) full-fat milk, (B) skim-milk, (C) Skim-milk treated with Tg, (D) skim-milk mixed with $\alpha$-lactalbumin and treated with Tg, (E) skim milk mixed with $\beta$-lactoglobulin and treated with $\mathrm{Tg}$ and (F) skim milk mixed with WPI and treated with Tg. 


\section{Conclusion}

Addition of whey protein products enhanced the reactivity of TG that represented in the extended clotting time and the marked increased curd yield with much less curd firmness as well as the appearance of new high molecular weight protein polymers bands in SDS-PAGE, compared to the other treatments with/without TG. It should be noted that the excessive crosslinking was more pronounced within WPI and $\beta$-lactoglobulin addition than that of $\alpha$-lactalbumin addition. The microstructure analysis confirms these findings through the presence of much closure and dense casein aggregates accompanied by clusters of WP strands attached to protein matrices with particular intense in STG-Beta and STG-WPI treatments.

In sum, the results of this study imply that $T G$ as well as whey protein products greatly altered the functional properties of the protein gel network. Among the whey protein products, WPI was of more recommended due to the highest curd yield as well as its nutritional value, compared to the individual whey protein fractions. The modified functional properties of the gel network obtained in this study contribute to further understanding of how different ingredients interact and modify casein-based structure, allowing manifold applications in dairy products with particular respect to the enhancement and optimization of low-fat cheese varieties.

\section{REFERENCES}

AOAC (1990). "Association of official analytical chemists. Official methods of analysis (15th ed.) " Association of Anal. Chem. INC., Suite 400, 2200, Wilson Boulevard, Arlington, Virginia 22201, USA.

Bauer, N., Koehler, P., Wieser, H. and Schieberle, P. (2003). "Studies on effects of microbial transglutaminase on gluten proteins of wheat. II. Rheological properties." Cereal Chem 80: 787-790.

Bönisch, M. P., Heidebach, h. C. and Kulozik, U. (2008). "Influence of transglutaminase protein cross-linking on the rennet coagulation of casein " Food Hydrocolloids 22: 288-297.

Eissa, A. S. and Khan, S. A. (2006). "Modulation of hydrophobic interactions in denatured whey proteins by transglutaminase enzyme." Food Hydrocolloids 20: 543-547.

Gauche, C., Vieira, J. T. C., Ogliari, P. J. and Bordignon-Luiz, M. T. (2008). "Crosslinking of milk whey proteins by transglutaminase." Process Biochemistry 43 788-794.

Hinz, K., Huppertz, T., Kulozik, U. and Kelly, A. L. (2007). "Influence of enzymatic cross-linking on milk fat globules and emulsifying properties of milk proteins." International Dairy Journal 17: 289-293.

International Dairy Federation (IDF) (1993). "Milk-determination of nitrogen content (Kjeldahl method)." Standard 20B (pp. 1-12). Brussels, Belgium.

Jaros, D., Jacob, M., Otto, C. and Rohm, H. (2010). "Excessive cross-linking of caseins by microbial transglutaminase and its impact on physical properties of acidified milk gels". Int. Dairy J., 20: 321-327. 
Kruif, C., Tuinier, R., Holt, C., Timmins, P. and Rollema, H. (2002). "Physicochemical study of k- and b-casein dispersions and the effect of cross-linking by transglutaminase." Langmuir 18: 4885-4891.

Kuraishi, C., Yamazaki, K. and Susa, Y. (2001). "Transglutaminase: its utilization in the food industry." Food Rev Int 17: 221-246.

Laemmli, U. (1970). "Cleavage of structural proteins during the assembly of the head of bacteriophage T4." Nature 227: 680-685.

Li,C. P., Enomoto, H., Ohki, S., Ohtomo, H. and Aoki, T. (2005). "Improvement of Functional Properties of Whey Protein Isolate Through Glycation and Phosphorylation by Dry Heating." J. Dairy Sci. 88:41374145

Ling, E. R. (1963). A text book of dairy chemistry Chapman \& Hall (eds.), London.

Liu, H., Xu, X. M. and Guo, S. D. (2008). "Comparison of full-fat and low-fat cheese analogues with or without pectin gel through microstructure, texture, rheology, thermal and sensory analysis." Int. J. Food Sci. \& Tech., 43: 1581-1592.

Lobato-Calleros, C., Ramirez-Santiago, C. and Vernon-Carter, E. J. (2002). "Microstructure and texture of manchego cheese-like products made with canola oil, lipophilic and hydrophilic emulsifiers." J. Texture Studies, 33: 165-182.

Lobato-Calleros, C., Reyes-Hernadez, J., Beristain, C. I., Hornelas-Uribe, Y., Sanches-Garcia, J. E. and Vernon-Carter, E. J. (2007). "Microstructure and texture of white fresh cheese made with canola oil and whey protein concentrate in partial or total replacement of milk fat." Food Res. Int., 40: 529-537.

McMahon, D. and Brown, R. (1982). "Evaluation of Formagraph for Comparing Rennet Solutions." J Dairy Sci 65: 1639-1642

Mugurama, M., Tsuruoka, K., Katamayma, K., Erwanto, Y., Kawahara, S., Yamauchi, K. and et al (2003). "Soybean and milk proteins modified by transglutaminase improves chicken sausage texture even at reduced levels of phosphate." Meat Sci 63(191-197).

Nielsen, G., Petersen, B. and Moller, A. (1995). "Impact of salt, phosphate and temperature on the effect of a transglutaminase (F XIIIA) on the texture of restructured meat." Meat Sci 41: 293-299.

O'Sullivan, M. M., Kelly, A. L. and Fox, P. F. (2002). "Influence of transglutaminase treatment on some physico-chemical properties of milk." Journal of Dairy Research 69: 433-442.

Puventhiran, A., Williams, R.P.W., and Augustin, M. A. (2002). "Structure and viscoelastic properties of set yogurt with altered casein to whey protein ratios". International Dairy Journal 12: 383-391.

Rodriguez-Nogales, J. (2006). "Effect of preheat treatment on the transglutaminasecatalyzed cross-linking of goat milk proteins." Process Biochem 41: 430-437.

Sandoval-Castilla, O., C. Lobato-Calleros, E. Aguirre-Mandujano, and E. J. Vernon-Carter. (2004). "Microstructure and texture of yogurt as influenced by fat replacers." International Dairy Journal 14: 151-159. 
Schorsch, C., Carrie, H. and Norton, I. T. (2000). "Cross-linking casein micelles by a microbial transglutaminase: influence of cross-links in acid-induced gelation." International Dairy Journal 10: 529-539.

Sharma, R., Lorenzen, P. and Qvist, K. (2001). "Influence of transglutaminase treatment of skim milk on the formation of $\square-(\square-$ glutamyl)lysine and the susceptibility of individual proteins towards crosslinking." Int Dairy J 1: 785-93.

Sharma, R., Zakora, M. and Qvist, K. (2002). "Susceptibility of an industrial alactalbumin concentrate to cross-linking by microbial transglutaminase." Int Dairy J 12: 1005-12.

Siu, N., Ma, C., Mock, W. and Mine, Y. (2002). "Functional properties of oat globulin modified by a calcium-independent microbial transglutaminase." J Agric Food Chem 50: 2666-2670.

SPSS (2001). " Statistical analysis for windows." Rel. 11.0.1. Chicago: SPSS Inc.

Supavititpatana, P., Wirjantoro, T. I. and Raviyan, P. (2009). "Effect of Sodium Caseinate and Whey Protein Isolate Fortification on the Physical Properties and Microstructure of Corn Milk Yogurt". CMU. J. Nat. Sci., 8: 247-263.

Tolkach, A. and Kulozik, U. (2005). "Fractionation of whey proteins and caseinomacro-peptide by means of enzymatic crosslinking and membrane separation techniques". Journal of Food Engineering, 67, $13-20$

Truong, V., Clare, D. A., Catignani, G. L. And Swaisgood, H. E. (2004). "Cross-Linking and Rheological Changes of Whey Proteins Treated with Microbial Transglutaminase". J. Agric. Food Chem., 52, 11701176.

Tseng, T., Chen, M. and Liu, D. (2002). "Purification of transglutaminase and its effects on myosin heavy chain and actin of spent hens." Meat Sci 60:267-270.

Wróblewska, B., Jędrychowski, L., Hajós, G. and Szabó, E. (2008). "Influence of Alcalase and transglutaminase on immunoreactivity of cow milk whey proteins." Czech J. Food Sci 26: 15-23. 


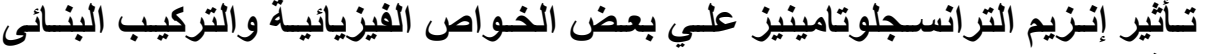

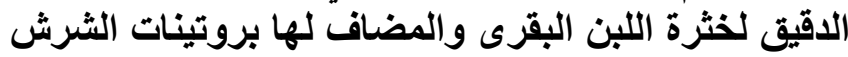

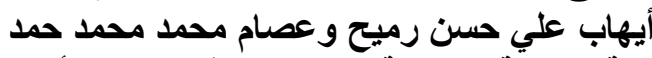 كلية الزراعة ـ جامعة القاهرة ــ ـ قسم علوم الألبان.}

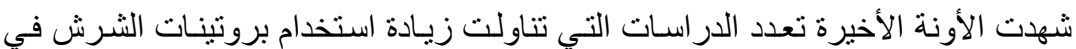

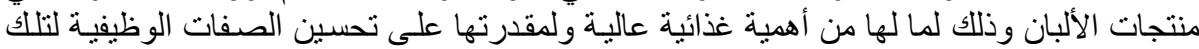

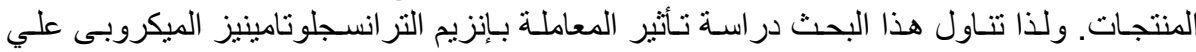

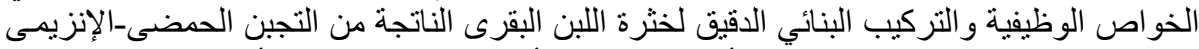

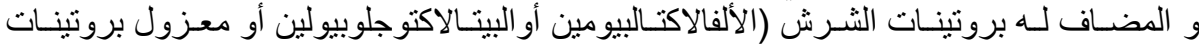

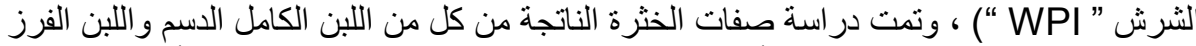

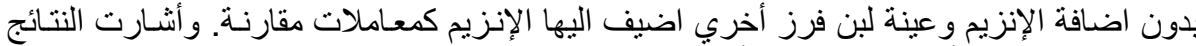

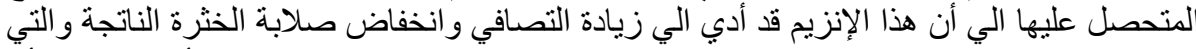

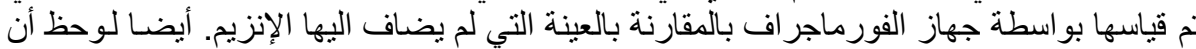

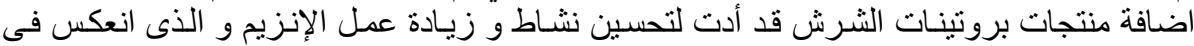

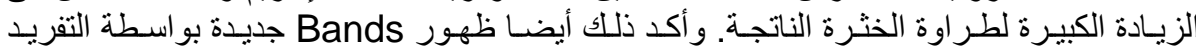

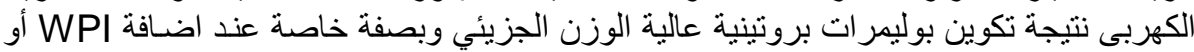

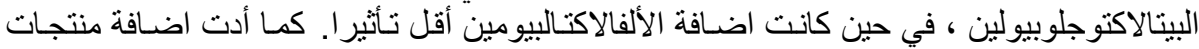

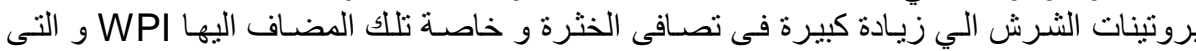

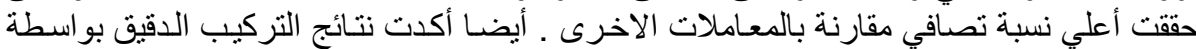

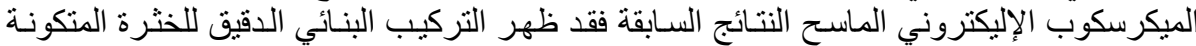

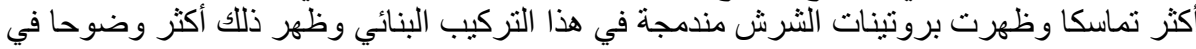
حالة اضافة WPI والبيتالاكتو جلو بيولين.

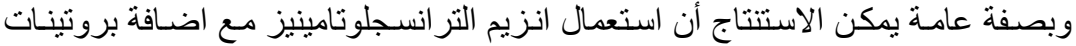

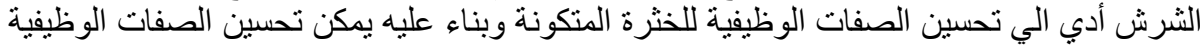
للمنتجات اللبنية بإضافة بروتينات الثرش قبل معاملة اللبن بانزيم التر انسجلو تامينيز.

كلية الزراعة - جامعة المنصورة

قام بتحكيم البحث

كلية الزراعة ـ جامعة القاهرة

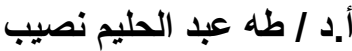

أ.د / منير محمود العبد الصلي 